\title{
Pengaruh Ketidakpastian Lingkungan Terhadap Perilaku Pegawai PEMDA dengan Ketidakpastian Tugas dan Job Insecurity Sebagai Variabel Moderasi
}

\author{
Dian Indriana Hapsari \& Endang Widyastuti
}

\begin{abstract}
In present era, public sector services are one of the major demands. Employees are requested to show their excellent performance. The success on the job implementation is influenced by external and internal factors. This study aims to determine the effect of environmental uncertainty on the employee behavior with task uncertainty and job Insecurity as a moderation variable. This study uses questionnaires as a measuring tool.

The subjects of this research are public service officer in Karanganyar, Sukoharjo, and Boyolali districts and also in a city of Surakarta City. The subject of the study is 127 people. The research shows that the coefficient of uncertainty in job implementation variable does not moderate the relationship between environmental uncertainty and employee behavior as shown by the significance coefficient of 0.889 . While job insecurity variables moderate the relationship between environmental uncertainty and employee behavior indicated by a significance value of 0.025 which is smaller than $5 \%$.
\end{abstract}

Keyword : Employee Behavior, Environmental Uncertainty, Task Uncertainty, and Job Insecurity

\section{Pendahuluan}

Saat ini layanan sektor publik menjadi salah satu tuntutan utama. Masyarakat membutuhkan kecepatan dan keakuratan layanan serta tidak menolerir pelayanan yang berbelit-belit. Kinerja karyawan pemerintah menuntut karyawan untuk mempunyai kapabilitas prima dan serta dukungan sarana dan prasarana pendukung. Akan tetapi, karyawan dengan keterampilan yang baik tidak dijamin akan mampu menunjukkan kinerja yang baik. Terdapat faktor-faktor di luar kendali

\section{Afiliasi Penulis}

Universitas Setia Budi Surakarta

Jl. Letjen Sutoyo, Mojosongo, Surakarta

Korespondensi kepada

D.I. Hapsari

canza_zone@yahoo.com karyawan yang bersangkutan untuk dapat menunjukkan kinerja yang baik.

Penelitian mengenai ketidakpastian lingkungan telah banyak dilakukan oleh beberapa peneliti di bidang akuntansi manajemen, seperti Fleming (2001), Krishnan et al., (2006), Rowley et al., (2000), Hariyanto dan Pinasti et al (2002), Anwar (2004), Sulaksono (2005), Wang and Shih-Chieh Fang (2010). Ketidakpastian lingkungan menimbulkan ketidakpastian tugas, kurangnya pemahaman tentang suatu kegiatan dan informasi mengenai proses pelaksanaan tugas (Hirst dalam Syam, 2001). Hal ini didukung oleh pernyataan Duncan (1972, pp. 318) yang menyatakan bahwa "The lack of information regarding the environmental factors [...] if the decision were incorrect, and inability to assign probabilities with any degree of confidence with regard to how environmental factors are going to affect the success or failure of the decision unit in performing its function". 
Dalam prakteknya, kebanyakan rotasi pekerjaan di Pemda memiliki nuansa politik yang tinggi (Thoha, 2002). Hal ini mengakibatkan terbentuknya sikap, perilaku, sistem, dan opini pimpinan bahwa kelembagaan birokrasi pemerintah sudah selayaknya mendukung kekuatan politik yang berkuasa. Akibatnya, pegawai bekerja berdasarkan perintah atasan (ekstrinsik) dan bukan berdasarkan kemampuan yang mereka miliki. Mereka akan merasa tidak aman dengan adanya rotasi jabatan ataupun non jabatan yang tidak dapat diprediksi.

Berdasarkan uraian di atas, penulis menduga nuansa politik yang tinggi akan memberikan dampak negatif terhadap moral dan perilaku yang akan mempengaruhi kinerja pegawai. Dampaknya diperkuat oleh ketidakpastian tugas dan job insecurity. Perilaku dan moral yang positif akan memotivasi dan meningkatkan kemampuan untuk menyelesaikan tugas atau pekerjaan (Rimandha, 2004). Nuansa politik yang tak menentu inilah yang menjadi suatu ketidakpastian lingkungan yang akan memunculkan ketidakpastian tugas dan job insecurity, [...] unpredictable and uncertain conditions have a considerable impact on organizational performance (Krishnan et al., 2006 pp. 894-917; Moorman and Miner, 1997 pp. 91106). Penelitian ini dapat memberikan pemahaman pentingnya faktor-faktor intrinsik seperti ketidakpastian lingkungan, ketidakpastian tugas, dan job insecurity dalam rangka menjalankan otonomi daerah.

Rotasi jabatan di Pemda biasanya memiliki nuansa politik yang tinggi. Hal ini mengakibatkan terbentuknya sikap, perilaku, sistem, dan opini para pimpinan bahwa kelembagaan birokrasi pemerintah sudah selayaknya mendukung kekuatan politik yang berkuasa. Akibatnya, pegawai bekerja berdasarkan perintah atasan (ekstrinsik) dan bukan berdasarkan kemampuan yang mereka miliki. Mereka akan merasa tidak aman dengan adanya job rotation ataupun non job yang tidak dapat diprediksi. Bersadarkan uraian diatas maka dapat rumusan masalah dalam penelitian ini adalah sejauh mana variabel ketidakpastian tugas dan job insecurity memoderasi hubungan antara ketidakpastian
Lingkungan terhadap perilaku pegawai di Lingkungan Pemerintah Daerah eks Karesidenan Surakarta

\section{Tinjauan Pustaka}

\section{Perilaku Pegawai}

Dharma (2003:34) mengemukakan bahwa "Perilaku pada dasarnya berorientasi tujuan, artinya bahwa perilaku orang pada umumnya dimotivasi oleh keinginan untuk meraih tujuantujuan tertentu". Berkaitan dengan birokrasi, perilaku pimpinan akan sangat berpengaruh terhadap kualitas birokrasi itu sendiri. Pernyataan tersebut sejalan dengan pandangan Rondinelli (dalam Simamora, 1995) yang mengatakan bahwa kualitas birokrasi pemerintahan lokal sangat ditentukan oleh perilaku, sikap dan kultur yang kondusif, sehingga mereka responsif untuk mengambil keputusan, memiliki kepedulian dan bertanggung jawab terhadap peningkatan program pembangunan bagi kesejahteraan masyarakat, terutama kelompok sasaran (penduduk miskin) yang perlu mendapat perhatian khusus.

Ketidakpastian tugas dapat didefinisikan sebagai perbedaan antara jumlah informasi yang dibutuhkan untuk menyelesaikan tugas dan jumlah informasi yang telah dimiliki oleh organisasi (Galbraith dalam Kim et al 1998). Kim et.al (dalam David, 2001) membagi ketidakpastian tugas dalam dua dimensi, yaitu ketidakpastian dalam tingkat kerumitan tugas (task analyzability) dan ketidakpastian dalam seberapa sering munculnya tugas yang tidak biasa (task variability). Apabila suatu perusahaan memberikan ketidakpastian tugas (task uncertainty) yang rendah dengan memberikan peraturan dan ketentuan yang jelas tentang pelaksanaan kerja, seperti adanya pembagian tugas yang jelas, menggunakan prosedur atau metode yang tetap, menugaskan orang yang berkompeten di bidangnya, dan tipe pekerjaan telah ditentukan sebelumnya, maka hal ini menyebabkan para manajer dapat bekerja dengan baik, tidak perlu melakukan penyesuaianpenyesuaian dalam pekerjaan, mudah mengikuti prosedur, tidak mengalami kesulitan dalam mengambil keputusan karena memiliki seluruh informasi yang dibutuhkan, dan tidak ada faktor- 
faktor lain yang dapat mempengaruhi keputusan para manajer yang bersangkutan (Syam dan Kusuma, 2001).

Greenhalgh dan Rosenblatt (dalam Greenglass et.al, 2002) mendefinisikan job insecurity sebagai ketidakberdayaan untuk mempertahankan kesinambungan yang diinginkan dalam kondisi kerja yang tidak aman. Sementara Smithson dan Lewis (2000) mengartikan job insecurity sebagai kondisi psikologis seorang karyawan yang menunjukkan rasa tidak aman dikarenakan kondisi lingkungan yang berubah-ubah (perceived impermanance). Kondisi ini muncul karena banyaknya jenis pekerjaan yang sifatnya sesaat atau pekerjaan kontrak. Makin banyaknya jenis pekerjaan dengan durasi waktu yang sementara atau tidak permanen, menyebabkan semakin banyaknya karyawan yang mengalami job insecurity (Smithson \& Lewis, 2000).

Hipotesis yang diberikan dalam penelitian ini menunjukkan adanya pengaruh antara ketidakpastian lingkungan, ketidakpastian tugas, dan job insecurity terhadap perilaku pegawai Pemda. Otonomi daerah yang seharusnya dapat dijalankan dengan professional nampaknya tidak mampu dijalankan dengan baik karena adanya nuansa politik yang tinggi di Pemerintah Daerah. Ketidakpastian lingkungan, ketidakpastian tugas, dan job insecurity memberikan pengaruh terhadap perilaku pegawai Pemda. Kinerja bukan lagi berdasarkan kemampuan, keterampilan, dan pengalaman kerja namun berdasarkan siapa pimpinan kita dan dukungan kita terhadap pimpinan tersebut. Jadi pegawai bekerja atas dasar ekstrinsik melihat siapa atasan mereka.

\section{Ketidakpastian Lingkungan}

Ketidakpastian lingkungan yang dirasakan oleh seorang pemimpin atau manajer menurut Miliken (dalam Rinarti dan Renyowijoyo, 2007) adalah jika manajer berada dalam ketidakpastian lingkungan dalam organisasinya atau khususnya komponenkomponen dalam lingkungannya yang tidak dapat diprediksi, mereka akan merasa tidak pasti terhadap tindakan relevan yang diambil berkenaan dengan pihak-pihak yang berhubungan dengannya. Penelitian sebelumnya membuktikan bahwa seseorang akan mengetahui dengan jelas prestasi yang dicapai bila ia bekerja dalam kondisi stabil (Hirst dalam Hariyanto dan Pinasti 2002). Hal ini dikarenakan dalam kondisi yang tidak stabil seseorang tersebut tidak memiliki informasi yang cukup untuk memprediksi masa depan secara tepat. Dalam kondisi ketidakpastian lingkungan yang rendah (kondisi relatif stabil) individu dapat memprediksi keadaan di masa depan sehingga langkah-langkah yang akan dilakukannya dapat direncanakan lebih akurat (Duncan dalam Fauziyah, 2000). Oleh sebab itu ketidakpastian lingkungan akan mempengaruhi perilaku dan kinerja manajer.

\section{Ketidakpastian Tugas}

Penulis menduga bahwa ketidakpastian tugas memoderasi pengaruh dari ketidakpastian lingkungan terhadap perilaku pegawai. Hal ini didasarkan pada analisa penulis, semakin tinggi ketidakpastian tugas maka semakin tinggi pula pengaruh ketidakpastian lingkungan terhadap perilaku pegawai. Penelitian sebelumnya menunjukkan bahwa ketidakpastian lingkungan akan menimbulkan ketidakpastian tugas karena kurangnya pemahaman tentang suatu kegiatan dan kurangnya informasi mengenai proses pelaksanaan tugas (Hirst dalam Syam, 2001). Lebih lanjut dikatakan oleh Brownell dan Hirst bahwa ketidakpastian tugas mempengaruhi kinerja manajer. Semakin tinggi ketidakpastian tugas maka kinerja manajer akan menurun dan sebaliknya.

Perbedaan antara jumlah informasi yang dibutuhkan untuk menyelesaikan tugas dan jumlah informasi yang telah dimiliki oleh organisasi ini lah yang menimbulkan ketidakpastian tugas (Galbraith dalam Kim et al 1998). Jika setiap sub-tugas dapat dianalisis dengan mudah, maka untuk melakukan analisis terhadap hubungan antara output dan inputnya juga akan jelas (Astuti, 2003). Apabila seorang manajer mengetahui tugas yang harus dikerjakannya dengan jelas, maka prestasi para manajer akan meningkat karena manajer tersebut bekerja dalam kondisi ketidakpastian tugas yang rendah. Sebaliknya, apabila manajer tidak mengetahui tugas yang harus dikerjakannya maka prestasi para manajer tersebut menurun karena berada dalam kondisi ketidakpastian tugas yang tinggi. 
$\mathrm{H}_{1}$ : Ketidakpastian tugas memoderasi pengaruh ketidakpastian lingkungan terhadap perilaku pegawai

\section{Job Insecurity}

Greenglass et.al (2002) mendefinisikan job insecurity sebagai ketidakberdayaan untuk mempertahankan kesinambungan yang diinginkan dalam kondisi kerja yang tidak aman. Dalam prakteknya, kebanyakan job rotation dan non-job di Pemda memiliki nuansa politik yang tinggi (Thoha, 2002). Hal ini mengakibatkan terbentuknya sikap, perilaku, sistem, dan opini para pimpinan bahwa kelembagaan birokrasi pemerintah sudah selayak-nya mendukung kekuatan politik yang berkuasa. Ketika pegawai di suatu instansi tersebut tidak mendukung pimpinan maka posisi atau jabatan mereka pun tidak aman.

$\mathrm{H}_{2}$ : Job insecurity memoderasi pengaruh ketidakpastian lingkungan terhadap perilaku pegawai.

\section{Metode}

\section{Kerangka Penelitian}

Penelitian dirancang untuk mengetahui pengaruh ketidakpastian lingkungan terhadap perilaku pegawai dengan memperhitungkan faktor ketidakpastian tugas dan job insecurity Pegawai Pemerintah Daerah wilayah Surakarta (gambar 1).

\section{Populasi dan Sampel}

Populasi penelitian adalah pegawai pemerintah di eks Karesidenan Surakarta. Pemilihan sampel didasarkan pada Metode pengambilan sampel bertujuan (purposive sampling), yaitu sampel

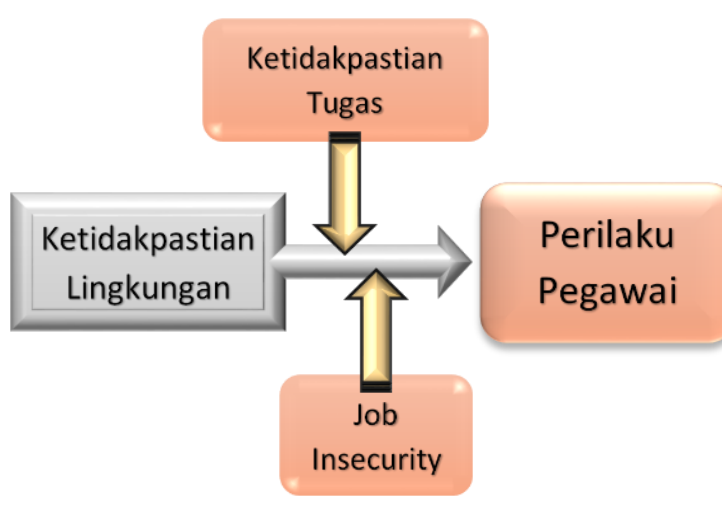

Gambar 1 | Kerangka Penelitian dipilih berdasarkan kriteria tertentu. Kriteria yang digunakan adalah berdasarkan pertimbangan (judgement), sehingga disebut sebagai judgment sampling. Kriteria yang digunakan dalam pengambilan sampel ini adalah pegawai struktural eselon 2-4 di SKPD (dinas, kantor, dan badan) dan sudah menjabat minimal selama 1 (satu) tahun. Pegawai struktural eselon 2-4 yang telah menjabat selama 1 (satu) tahun atau lebih di SKPD, dipandang telah memiliki pemahaman terhadap situasi dan kondisi yang ada di dalam SKPD serta terlibat dalam pengambilan keputusan.

\section{Instrumen Pengukuran}

Ketidakpastian lingkungan dalam hal ini adalah kondisi dimana SKPD mengalami ketidakpastian yang dapat disebabkan adanya pengaruh dari luar SKPD, seperti sering terjadinya perubahan pimpinan, terjadinya mutasi staf, job rotation, maupun non job SKPD yang cepat, dan lain sebagainya. Variabel ini diukur dengan menggunakan instrument dari Duncan yang terdiri dari 12 item pertanyaan dengan poin skala Likert 15. Instrumen ini juga telah digunakan oleh peneliti seperti Gul dan Chia (1994), Gregson et al (1994), Muslimah (1998) dan Isti (1999).

Ketidakpastian tugas dalam hal ini adalah aturan pelaksanaan tugas. Instrumen ketidakpastian tugas diukur dengan mengembangkan pertanyaan yang dilakukan oleh Hirst dan Withey et. al. yang kemudian dikembangkan oleh Saleke (1994) (dikutip dari Fazli Syam 2001) dengan menekankan pada tingkat ketidakpastian tugas pegawai dalam bekerja. Terdapat empat instrument pertanyaan yang digunakan untuk mengukur ketidakpastian tugas dengan lima poin skala Likert.

Job Insecurity dalam hal ini adalah kondisi di mana pegawai merasakan ketidakamanan kerja karena adanya ancaman mengenai kelangsungan bekerja atau ancaman kehilangan pekerjaan di waktu yang akan datang yang akan menyebabkan dampak negatif terhadap kinerja maupun psikologis pegawai. Alat ukur job insecurity yang digunakan dalam penelitian ini adalah modifikasi dari job insecurity scale yang dikembangkan oleh Patrina (2002). Terdapat lima instrument 
Tabel 1 | Jumlah responden dan kuesioner di 4 wilayah

\begin{tabular}{c|llcc} 
No & \multicolumn{1}{|c}{ Wilayah } & \multicolumn{1}{c}{ Tanggal } & $\begin{array}{c}\text { Jumlah } \\
\text { Responden }\end{array}$ & $\begin{array}{c}\text { Kuesioner } \\
\text { diterima }\end{array}$ \\
\hline 1 & Kota Surakarta & 1 Agustus 2016 & 56 & 42 \\
2 & Kabupaten Karanganyar & 1 Agustus 2016 & 50 & 44 \\
3 & Kabupaten Sukoharjo & 8 Agustus 2016 & 44 & 32 \\
4 & Kabupaten Boyolali & 1 Agustus 2016 & 50 & 34 \\
\hline
\end{tabular}

pertanyaan yang digunakan untuk mengukur job insecurity dengan lima poin skala Likert.

Perilaku pegawai dalam hal ini adalah kemampuan pegawai dalam pelaksanaan tugasnya, termasuk moral dari pegawai tersebut. Menurut Ramanauskas dan Marconi (dalam Hariyanto dan Pinasti, 2002), pada hakekatnya organisasi dijalankan oleh manusia, maka penilaian kinerja sebenarnya merupakan penilaian atas perilaku manusia dalam melaksanakan perannya dalam organisasi. Instrumen perilaku diukur dengan menggunakan item-item pertanyaan yang berkaitan dengan sikap dan tindakan responden terhadap penilaian prestasi dan kinerja. Ukuran perilaku manajer diambil dari seberapa besar nilai sikap dan tindakan yang mereka ambil. Sikap dan tindakan ini dinilai dengan menggunakan skala Likert 1 (sangat rendah) sampai 5 (sangat tinggi).

\section{Teknik Analisis Data}

Metode analisis yang digunakan dalam penelitian ini menggunakan hierarchical regression dengan menggunakan SPSS versi 17. Beberapa indikator uji yang penting untuk mengetahui kebaikan model regresi adalah: (a) menentukan besaran koefisien determinasi, (b) menguji signifikansi model regresi, uji signifikansi model regresi ini dilakukan dengan uji F (Overall Test), dan (c) Estimasi Koefisien Regresi. Estimasi besarnya koefisien regresi dilakukan dengan uji $t$ (Individual Test).

\section{Hasil}

Berdasarkan kuesioner yang dibagikan di 4 (empat) wilayah Kotamadya/Kabupaten, kuesioner yang terkumpul adalah 152 terdapat sejumlah data yang tidak bisa diolah disebabkan karena pengisian kuesioner yang tidak lengkap (tabel 1). Adapun jumlah kuesioner yang pengisiannya tidak lengkap sejumlah 25, sehingga kuesioner yang bisa diolah sejumlah 127.

\section{Uji Instrumen Penelitian}

Sebelum dilakukan uji hipotesis penelitian, terlebih dahulu dilakukan uji coba instrumen penelitian. Terdapat dua macam analisa kuesioner, yaitu uji validitas instrumen penelitian, yang diuji menggunakan analisis faktor, serta uji reliabilitas instrumen penelitian, untuk mengetahui sejauh mana instrumen penelitian tersebut dapat dipercaya. Hasil analisis faktor alat ukur penelitian dapat dilihat dalam tabel 2 .

Lebih lanjut, peneliti melakukan uji reliabilitas instrumen penelitian untuk mengetahui tingkat keterpercayaan alat ukur. Hasil uji reliabilitas disajikan dalam tabel 3.

Tabel 2 | Hasil uji analisis faktor berupa matriks komponen. Component

\begin{tabular}{|c|c|c|c|c|}
\hline & 1 & 2 & 3 & 4 \\
\hline KL5 & .758 & & & \\
\hline KL6 & .776 & & & \\
\hline KL7 & .736 & & & \\
\hline KL8 & .756 & & & \\
\hline KL11 & .807 & & & \\
\hline Jl11 & & .503 & -.504 & \\
\hline II2 & & .795 & & \\
\hline JI33 & & .694 & & \\
\hline JI58 & & .632 & & \\
\hline PP9 & & .407 & .660 & \\
\hline PP21 & & .460 & & \\
\hline PP29 & -.465 & & .639 & \\
\hline KT1 & .591 & & & .658 \\
\hline KT3 & .642 & & & .532 \\
\hline
\end{tabular}

Extraction Method: Principal Component Analysis. a. 4 components extracted 
Tabel 3 | Hasil uji reliabilitas kuesioner

\begin{tabular}{rcc} 
Variabel & $\begin{array}{c}\text { Koefisien } \\
\text { Alpha }(\alpha)\end{array}$ & Keterangan \\
\hline Ketidakpastian lingkungan (KL) & 0,8648 & Reliabel \\
Job insecurity (JI) & 0,9906 & Reliabel \\
Perilaku pegawai (PP) & 0,6497 & Reliabel \\
Ketidakpastian tugas (KT) & 0,7078 & Reliabel
\end{tabular}

Sumber: data primer yang diolah

Terlihat semua butir kuesioner valid dalam variabel yang diteliti, mempunyai nilai reliabilitas lebih besar dari 0,6 sehingga dapat disimpulkan butir kuesioner tersebut reliabel digunakan mengukur variabel.

\section{Deskripsi Data Penelitian}

Berdasarkan hasil penelitian diperoleh gambaran tentang data penilaian pada masing-masing variabel, sebagaimana yang tersaji pada tabel 4 . Hasil perhitungan data hipotesis dan data empiris lebih lanjut dipergunakan sebagai dasar pengkategorisasian subyek penelitian. Norma kategori dibuat berdasarkan perbandingan antara data empiris dibandingkan dengan rerata dan standar deviasi hipotesis.

\section{Hasil Uji Hipotesis Penelitian}

Penelitian ini bertujuan untuk mengetahui pengaruh ketidakpastian lingkungan terhadap perilaku pegawai dengan job insecurity dan ketidakpastian tugas sebagai variabel moderasi.

Tabel 4 | Data empiris skala penelitian

\begin{tabular}{rcc} 
Variabel & Rerata & SD \\
\hline Perilaku pegawai & 5.7931 & 1.35679 \\
Ketidakpastian lingkungan & 6.0621 & 1.04587 \\
Job insecurity & 4.6272 & 1.52675 \\
Ketidakpastian tugas & 6.0172 & 1.19588 \\
\cline { 2 - 3 }
\end{tabular}

Korelasi antar variabel tersebut disusun dalam matriks korelasi antar variabel (tabel 5).

\section{Hasil Analisis Persamaan Regresi}

Untuk mengetahui pengaruh ketidakpastian lingkungan (KL) terhadap perilaku pegawai (PP) dengan job insecurity (JI) dan ketidakpastian tugas (KT) sebagai variabel moderasi, maka dilakukan uji regresi dengan Ketidakpastian tugas sebagai pemoderasi dan uji regresi dengan Job insecurity sebagai pemoderasi. Adapun hasil analisis regresinya adalah sebagai berikut :

1. Hasil analisis regresi dengan Ketidakpastian tugas sebagai pemoderasi

$$
\begin{aligned}
& P P=4.243+0.034(K L) \\
& \mathrm{PP}=4.008+0.146(\mathrm{KL})+0.431(\mathrm{KT}) \\
& P P=3.669+0.560(K L)+0.747(K T)-0.889 \\
& (\mathrm{KL})(\mathrm{KT})
\end{aligned}
$$

Berdasarkan hasil analisis persamaan 2, terlihat pengaruh KT tidak signifikan. Dalam persamaan 3, variabel interaksi $(\mathrm{KL})(\mathrm{KT})$ juga tidak signifikan. Oleh karena itu dapat disimpulkan bahwa variabel Ketidakpastian tugas tidak memoderasi hubungan antara Ketidakpastian lingkungan dan Perilaku pegawai.

2. Hasil analisis regresi dengan Job insecurity sebagai pemoderasi

$$
\begin{aligned}
& P P=4.243+0.034(K L) \\
& P P=4.797+0.019(K L)-0.060(J) \\
& P P=11.088-0.118(\mathrm{KL})-0.013(\mathrm{JI})+0.023 \\
& (\mathrm{KL})(\mathrm{JI})
\end{aligned}
$$

Hasil analisis persamaan 5 menunjukkan pengaruh JI tidak signifikan terhadap pembentukan Perilaku Pegawai. Dalam persamaan 6 variabel interaksi $(\mathrm{KL})(\mathrm{JI})$ berpengaruh signifikan. Oleh

Tabel 5 | Hasil uji reliabilitas kuesioner

\begin{tabular}{rcccc} 
Variabel & $\begin{array}{c}\text { Perilaku } \\
\text { Pegawai }\end{array}$ & $\begin{array}{c}\text { Ketidakpastian } \\
\text { Lingkungan }\end{array}$ & Job insecurity & $\begin{array}{c}\text { Ketidakpastian } \\
\text { tugas }\end{array}$ \\
\hline Perilaku pegawai & 1.000 & $.197^{*}$ & -.148 & $.164^{*}$ \\
Ketidakpastian lingkungan & .197 & 1.000 & .118 & $.516^{*}$ \\
Job insecurity & -.148 & .118 & 1.000 & .000 \\
Ketidakpastian tugas & .164 & .516 & .000 & 1.000
\end{tabular}

Keterangan: ${ }^{*}$ ) terdapat korelasi dengan taraf signifikansi $<5 \%$ 
karena itu dapat disimpulkan bahwa variabel Job insecurity merupakan variabel pemoderasi sejati hubungan antara Ketidakpastian lingkungan dan Perilaku pegawai.

\section{Pembahasan}

Berdasarkan hasil analisis data diketahui bahwa ketidakpastian lingkungan berkorelasi dengan perilaku pegawai. Individu mempersepsi ketidakpastian lingkungan yang tinggi jika merasa lingkungan tidak dapat diprediksi dan tidak dapat memahami bagaimana komponen lingkungan akan berubah (Krishnan et al., 2006). Sebaliknya, dalam kondisi ketidakpastian lingkungan yang rendah (kondisi relatif stabil) individu dapat memprediksi keadaan di masa depan sehingga langkah-langkah yang akan dilakukannya dapat direncanakan lebih akurat (Duncan dalam Fauziyah, 2000). Ketidakpastian lingkungan berpengaruh terhadap perilaku pegawai. Penelitian sebelumnya membuktikan bahwa seseorang akan mengetahui dengan jelas prestasi yang dicapai bila ia bekerja dalam kondisi stabil (Hirst dalam Hariyanto dan Pinasti 2002). Hal ini dikarenakan dalam kondisi yang tidak stabil seseorang tersebut tidak memiliki informasi yang cukup untuk memprediksi masa depan secara tepat.

Hasil analisis data menunjukkan bahwa ketidakpastian tugas tidak memoderasi ketidakpastian lingkungan terhadap perilaku pegawai. Perusahaan memberikan ketidakpastian tugas (task uncertainty) rendah yang tercermin dari peraturan dan ketentuan yang jelas tentang pelaksanaan kerja, seperti adanya pembagian tugas yang jelas, menggunakan prosedur atau metode yang tetap, menugaskan orang yang berkompeten di bidangnya, dan tipe pekerjaan telah ditentukan sebelumnya, menyebabkan para manajer dapat bekerja dengan baik, tidak perlu melakukan penyesuaian-penyesuaian dalam pekerjaan, mudah mengikuti prosedur, tidak mengalami kesulitan dalam mengambil keputusan karena memiliki seluruh informasi yang dibutuhkan (Syam dan Kusuma, 2001).

Penelitian Chong (1996) menunjukkan bahwa dalam situasi yang penuh ketidakpastian tugas mengakibatkan peningkatan efektifitas pengambil- an keputusan manajerial. Pada sisi yang lain, ketidakpastian tugas yang rendah berdampak pada peningkatan jumlah informasi, sehingga performansi manajerial menjadi tidak optimal.

Hasil analisis regresi lebih lanjut menunjukkan bahwa variabel job insecurity memoderasi hubungan antara ketidakpastian lingkungan dan Perilaku pegawai. Penelitian Adekiya (2015) menyatakan bahwa persepsi terhadap job insecurity berdampak pada kesehatan karyawan dan organisasi, dan juga akan berpengaruh terhadap kondisi ekonomi dan sosial masyarakat luas. Chirumbolo \& Areni (2005) menyatakan bahwa job insecurity berkorelasi negatif kinerja karyawan dan berkorelasi positif terhadap absensi. Akan tetapi sikap karyawan terhadap pekerjaan hanya memoderasi hubungan job insecurity dengan performa kerja, tetapi tidak berpengaruh terhadap absensi.

\section{Kesimpulan}

Studi ini menunjukkan bahwa Ketidakpastian tugas tidak memoderasi hubungan ketidakpastian lingkungan dan perilaku pegawai. Hal ini tidak sejalan dengan penelitian sebelumnya yang menunjukkan bahwa ketidakpastian lingkungan akan menimbulkan ketidakpastian tugas karena kurangnya pemahaman tentang suatu kegiatan dan kurangnya informasi mengenai proses pelaksanaan tugas (Hirst dalam Syam, 2000).

Studi ini juga menunjukkan bahwa Job Insecurity memoderasi hubungan antara ketidakpastian lingkungan dan perilaku pegawai. Hal ini mendukung penelitian sebelumnya yang dilakukan oleh Adekiya (2015) yang menyatakan bahwa persepsi terhadap job insecurity berdampak pada kesehatan karyawan dan organisasi, dan juga akan berpengaruh terhadap kondisi ekonomi dan sosial masyarakat luas.

\section{Bibliografi}

1. Adekiya, AA. 2015. Perceived Job Insecurity: Its Individual, Organizational and Societal Effects. European Scientific Journal. Vol.1 ISSN: 1857 - 7881 (Print) e - ISSN 1857- 7431.

2. Anwar, Kasyful. 2004. Pengaruh Ketidakpastian Tugas dan Ketidakpastian Lingkungan yang Dipersepsikan 
terhadap Hubungan Informasi Akuntansi dengan Kinerja Manajer. Tesis Universitas Diponegoro (dipublikasikan). Semarang.

3. Astuti, Sri, 2003, "Pengaruh Diversitas Kemanfaatan dan Lingkup Pengembangan Kemanfaatan Teknologi Informasi Terhadap Kepuasan Pemakai: Ketidakpastian Tugas Sebagai Faktor Moderasi", Kompak, No. 7, Januari- April: 94-117.

4. Chenhall, R. H. 2004. The Role of Cognitive and Affective Conflict in Early Implementation of Activity-Bast Cost Management. Behavioral Research in Accounting. Vol. 16, pp. 19-44.

5. Chirumbolo, A. \& Areni, A. 2005. The Influence of Job Insecurity on Job Performance and Absenteeism: the Moderating Effect of Work Attitudes. SA Journal of Industrial Psychology, 31 (4), 65-71

6. Chong, VK.. 1996. Management Accouting Systems, Task Uncertainty and Managerial Performance: A Research Note. Accounting, Organizations and Society, Vol. 21, No. 5, pp. 415 421,1996

7. Christina, Vita. 2010. Pengaruh Partisipasi Anggaran terhadap Senjangan Anggaran dengan Ketidakpastian Lingkungan sebagai Variabel Moderating pada Pt Perusahaan Gas Negara (Persero) Tbk. Universitas Sumatera Utara (dipublikasikan). Medan.

8. Fibrianti dan Riharjo. 2013. "Pengaruh Partisipasi Anggaran, Desentralisasi, Komitmen Organisasi, dan Ketidakpastian Lingkungan terhadap Kinerja Manajerial pada Pemerintahan Kota Surabaya." Jurnal IImu dan Riset Akuntansi, Januari 2013: 108-121.

9. Fitri, Fauziah A. 2000. Pengaruh Organizational Commitment, Information Asymmetry dan Budget Emphasis dalam Hubungan antara Partisipasi dan Slack Anggaran. Tesis Universitas Gadjah Mada. Yogyakarta.

10. Fleming, L. (2001), "Recombinant uncertainty in technological search", Management Science, Vol. 47 No. 1, pp. 117-32.

11. Greenberg, J \& Baron, R A. 2003. Behavior in Organization (8th ed). Singapore: Allyn \& Bacon.

12. Greenglass, Esther, Ronald Burke and Lisa Fiksenbaum. 2002. "Impact of Restructuring, Job Insecurity and Job Satisfaction in Hospital Nurses." Sress News January, 14(1):1-10.

13. Hariyanto, Eko dan Margani Pinasti, 2002, "Pengaruh Keikutsertaan Manajer Dalam Penyusunan Budget Terhadap Perilaku Manajer yang Kinerjanya Dinilai Dengan Informasi Akuntansi", Simposium Nasional Akuntansi V, September: 674-685.

14. Hoque, Z. 2005. Linking environmental uncertainty to non-financial performance measures and performance: a research note. The British Accounting Review, Volume 37, Issue 4, hal 471-481
15. Hyvonen, J. 2007. "Strategy, Performance Measurement Techniques and Information Technology of The Firm and Their Links to Organizational Performance". Management accounting research, Vol. 18. Pp. 343-366.

16. Krishnan, R., Martin, X. and Noorderhaven, N.G. (2006), "When does trust matter to alliance performance?", Academy of Management Journal, Vol. 49 No. 5, pp. 894-917.

17. Lili-Anne Kihn, (2010) "Performance outcomes in empirical management accounting research: Recent developments and implications for future research", International Journal of Productivity and Performance Management, Vol. 59 Iss: 5, pp.468 - 492.

18. Rimandha, Yosita. 2004. Pengaruh Ketidakpastian Tugas terhadap Perilaku Manajer. Universitas Katolik Soegijapranata. Semarang.

19. Rinarti, Deasy \& Renyowijoyo, Muindro. 2007. "Pengaruh Ketidakpastian Lingkungan dan Budaya Organisasi terhadap Partisipasi Penganggaran dan Kinerja Manajerial." Jurnal Bisnis dan Akuntansi. Vol. 8, No. 2, 124-135.

20. Sulaksono,Tri. 2005. Budaya Organisasi dan Ketidakpastian Lingkungan sebagai Variabel Moderating dalam Hubungan antara Gaya Evaluasi Atasan terhadap Tekanan Kerja dan Kepuasan Kerja Bawahan. Tesis Universitas Diponegoro (dipublikasikan). Semarang.

21. Schulz, A., Wu, A., \& Chee W.C. 2010. Environmental Uncertainty, Comprehensive Performance Measurement Systems, Performance-Based Compensation, and Organizational Performance. AsiaPacific Journal of Accounting \& Economics 17. Hal. 1740

22. Syam, Fazli. BZ dan I.W.Kusuma. 2001. "Pengaruh Informasi Akuntansi dan Ketidakpastian Tugas terhadap Perilaku Manajer: Sebuah Eksperimen Semu". SNA. $p$. 250-276.

23. Thoha, Miftah. 2002. "Reformasi Birokrasi Pemerintah." Seminar Good Governance. Universitas Gadjah Mada. Yogya 